\title{
ERRATUM: Correction of Title
}

\section{요추 추간판탈출증 환자에 대한 봉약침과 CS약침을 병행한 한의학적 복합치료 효과에 대한 증례보고}

\author{
황지혜 ${ }^{\odot} \cdot$ 김덕현 ${ }^{\circledR}$ \\ 가천대학교 한의과대학 침구의학교실
}

\section{Case Report of Two Cases on Effect of Combined Bee Venom and CS Pharmacopuncture with Koream Medicine Treatment on HIVD of L-spine}

\author{
Ji Hye Hwang, Deok-Hyun Kim
}

Department of Acupuncture \& Moxibustion Medicine, College of Korean Medicine, Gachon University

The authors of "Case Report of Two Cases on Effect of Combined Bee Venom and CS Pharmacopuncture with Koream Medicine Treatment on HIVD of L-spine" (Korean J. Acupunct. 2018 ; 35(4) : 239-246) requested for correction of title due to misdescription of a part of published title. The corrected title should be as follows:

A Case Report of Two Patients on the Effect of Bee Venom and CS Pharmacopuncture Combined with Korean Medicine Treatment for HIVD of L-spine. 